\title{
OPEN Catestatin in innate immunity and Cateslytin-derived peptides against superbugs
}

\author{
Francesco Scavello ${ }^{1,2}$, Angela Mutschler ${ }^{1}$, Sophie Hellé ${ }^{1,3}$, Francis Schneider ${ }^{1,3,4}$, \\ Sylvette Chasserot-Golaz ${ }^{5}$, Jean-Marc Strub ${ }^{6}$, Sarah Cianferani ${ }^{6}$, Youssef Haikel ${ }^{1,7}$ \& \\ Marie-Hélène Metz-Boutigue ${ }^{1 \bowtie}$
}

Chromogranin A (CgA) is the precursor of several antimicrobial peptides, such as Catestatin (Cts, bovine CgA344-364), initially described as a potent inhibitor of catecholamines. This peptide displays direct antimicrobial activities and contributes to immune system regulation. The aim of the present study is to investigate a designed peptide based on Cts to fight infections against superbugs and more particularly Staphylococcus aureus. In addition to Cateslytin (Ctl, bovine CgA344-358), the active domain of Catestatin, several peptides including dimers, D-isomer and the new designed peptide DOPA-K-DOPA-K-DOPA-TLRGGE-RSMRLSFRARGYGFR (Dopa ${ }_{5} \mathrm{~T}-\mathrm{Ctl}$ ) were prepared and tested. Cateslytin is resistant to bacterial degradation and does not induce bacterial resistance. The interaction of Catestatin with immune dermal cells (dendritic cells DC1a, dermal macrophages CD14 and macrophages) was analyzed by using confocal microscopy and cytokine release assay. The dimers and $\mathrm{D}$-isomer of $\mathrm{Ctl}$ were tested against a large variety of bacteria showing the potent antibacterial activity of the $\mathrm{D}$-isomer. The peptide $\mathrm{Dopa}_{5} \mathrm{~T}-\mathrm{Ctl}$ is able to induce the self-killing of $S$. aureus after release of $\mathrm{Ctl}$ by the endoprotease Glu-C produced by this pathogen. It permits localized on-demand delivery of the antimicrobial drug directly at the infectious site.

Some infections caused by antimicrobial-resistant microorganisms often no longer respond to conventional antibiotics $^{1}$. In the last decade, several multidrug-resistant high-risk strains have evolved due to the selective pressure of antimicrobial use ${ }^{2}$. The ever increasing number of such microorganisms has become a great and global public health threat worldwide among vulnerable populations such as immuno-suppressed and critically ill patients ${ }^{3}$. There is an urgent need to develop new antimicrobial compounds to fight against these superbugs. Host-defense peptides (HDPs) have emerged as new attractive candidates in the development of new antimicrobial agents ${ }^{4}$. Recently, a growing body of evidence suggests the biology and immunology of HDPs extends beyond the classical direct antimicrobial activity with the regulation of immune cells properties ${ }^{5}$.

We have previously shown that the pro-hormone chromogranin A (CgA) is the precursor of several physiological antimicrobial peptides ${ }^{6-9}$. In particular, $\mathrm{CgA}$ is an acidic glyco-phospho-protein stored in secretory vesicles of numerous nervous, neuroendocrine and immune cells. It is proteolytically cleaved by prohormone convertases, cathepsin L, plasmin and kallikrein to generate biologically active peptides released upon stress in most of the body fluids ${ }^{10}$. One of these HDPs, Catestatin (Cts, bovine CgA344-364) was initially described as a potent inhibitor of catecholamines release ${ }^{11}$. In addition, Cts plays a crucial role in cardiovascular system ${ }^{12,13}$, it displays direct antimicrobial activities ${ }^{9}$, it contributes to the immune system regulation and it modulates severe inflammatory response ${ }^{14-20}$. It was established that Cateslytin (Ctl, bovine CgA344-358) is the active core of

\footnotetext{
${ }^{1}$ BioMaterials and BioEngeneering, Institut National de la Santé et de la Recherche Médicale UMR_S 1121, Federation of Translational Medicine Faculty, of Odontology, University of Strasbourg, Hôpital Civil, Porte de L'Hôpital, 67000 Strasbourg, France. ²Department of Biology, Ecology and Earth Science, University of Calabria, Arcavacata di Rende, Italy. ${ }^{3}$ Faculty of Medicine, University of Strasbourg, Strasbourg, France. "Médecine Intensive-Réanimation, Hautepierre Hospital, Hôpitaux Universitaires, Strasbourg, Federation of Translational Medicine, Faculty of Medicine, University of Strasbourg, Strasbourg, France. ${ }^{5}$ Centre National de la Recherche Scientifique, Institut des Neurosciences Cellulaires et Intégratives, University of Strasbourg, Strasbourg, France. ${ }^{6}$ Centre National de la Recherche Scientifique, Laboratory of Bio-Organic Mass Spectrometry, Analytical Sciences Department, Pluridisciplinary Institute Hubert Curien, UMR 7178, University of Strasbourg, Strasbourg, France. ${ }^{7}$ Faculty of Odontology, University of Strasbourg, Strasbourg, France. ${ }^{\square}$ email: marie-helene.metz@ inserm.fr
} 


\section{1- Immunomodulation}

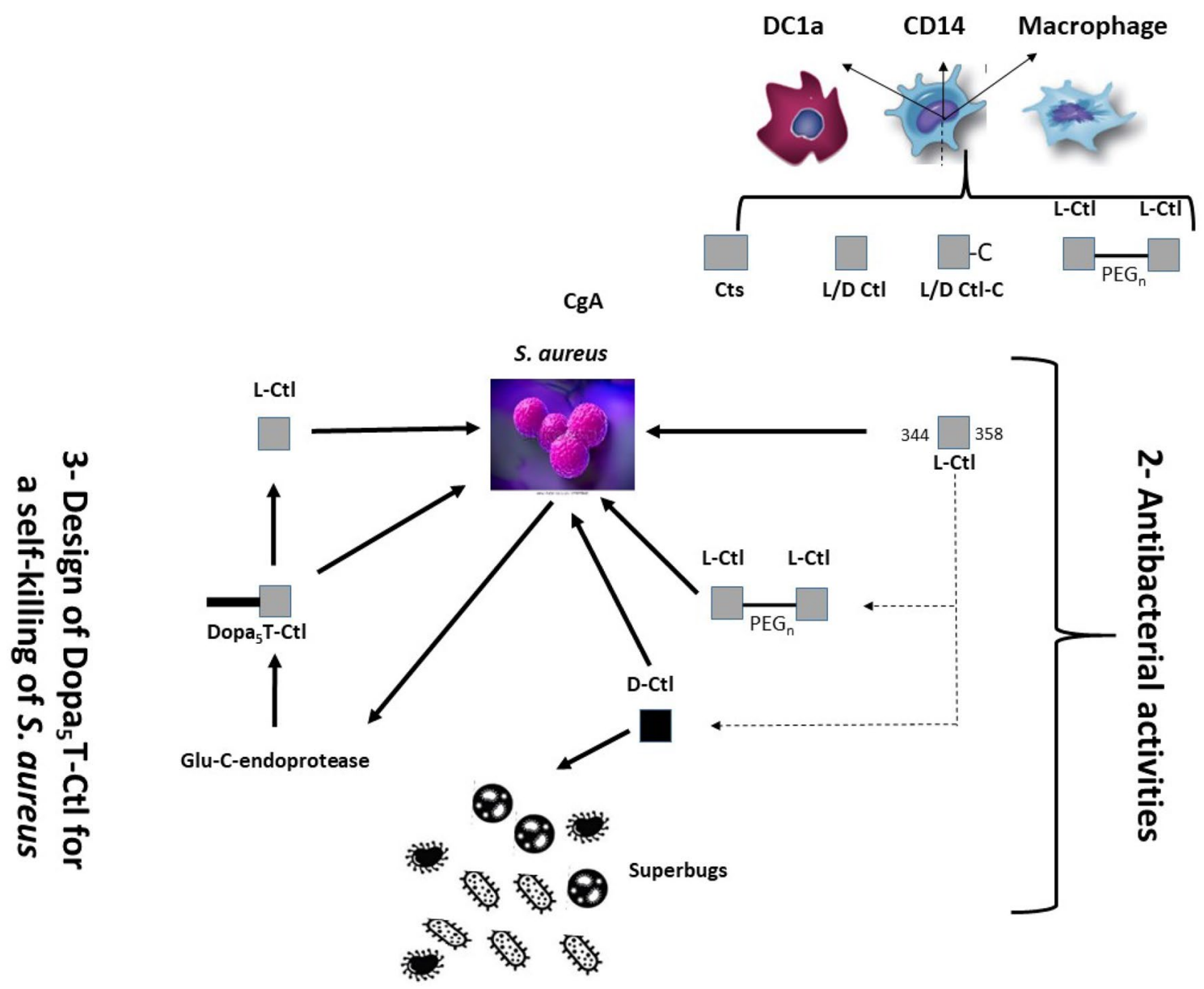

Figure 1. Outline of the study. 1-Immunomodulation: Interactions of Cts and its derived-peptides with immune cells are investigated; 2-The antibacterial activities of Ctl and the derived- peptides are examined; $3-$ The tri-blocks peptide Dopa $\mathrm{a}_{5} \mathrm{~T}-\mathrm{Ctl}$ for the on-demand delivery of $\mathrm{Ctl}$ is tested.

$\mathrm{Cts}^{9,21}$ and it is resistant to degradation by the proteases produced by Staphylococcus aureus ${ }^{22}$. Cts and Ctl show a broad spectrum of antimicrobial activities against bacteria and yeasts once attached to biomaterials ${ }^{23,24}$. A new strategy has been proposed by linking Cts to materials through a spacer which can be cleaved by hyaluronidase, an enzyme from S. aureus and Candida albicans ${ }^{23}$. Our group has previously characterized the antimicrobial and mechanistic properties of the D-isomer of Ctl, where all L-amino acids were substituted by D-amino acids ${ }^{25,26}$.

This manuscript focuses on the ability of Cts-derived peptides at killing superbugs and more particularly $S$. aureus, a pathogen important in dermal infections ${ }^{27}$. The outline of the present study is (i) to investigate the interaction of Cts with dermal immune cells (dendritic cells DC1a, dermal macrophages CD14 and macrophages) and to analyze the cytokines release, (ii) to screen the antimicrobial activity of several Cts-derived peptides against superbugs (dimers separated by PEG linkers, D-isomer) and (iii) to design a new Ctl-derived peptide able to induce an on-demand self-killing of S. aureus (Fig. 1). This peptide corresponds to a tri-blocks peptide DOPA-K-DOPA-K-DOPA-TLRGGE-RSMRLSFRARGYGFR (DOPA 5 T-Ctl, Supplementary Fig. 1), which might release Ctl after proteolysis by the endoprotease Glu-C (E.C. 3.4.21.19) produced by S. aureus ${ }^{28}$. To design this peptide, functional molecules were attached using a previously reported technology ${ }^{29,30}$.

This study underscores that (i) the dimeric form of Ctl linked by 3 PEGs enhances the antibacterial activity against $S$. aureus, (ii) the D-Ctl peptide displays activity against superbugs, and (iii) the peptide $\mathrm{DOPA}_{5} \mathrm{~T}-\mathrm{Ctl}$ is not toxic and could be used in new strategies for the self-killing of $S$. aureus and the modulation of cellular immunity based on the localized and sustained release of Ctl. 
$\mathbf{a}$

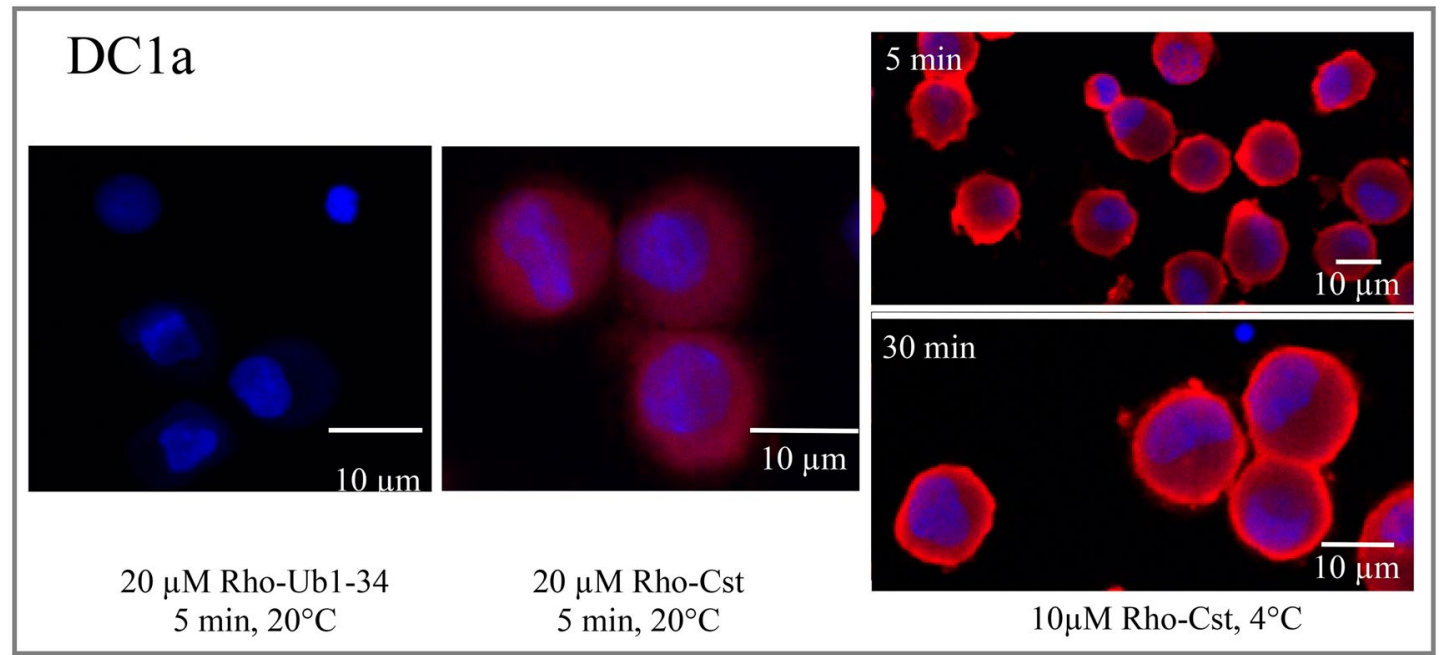

b

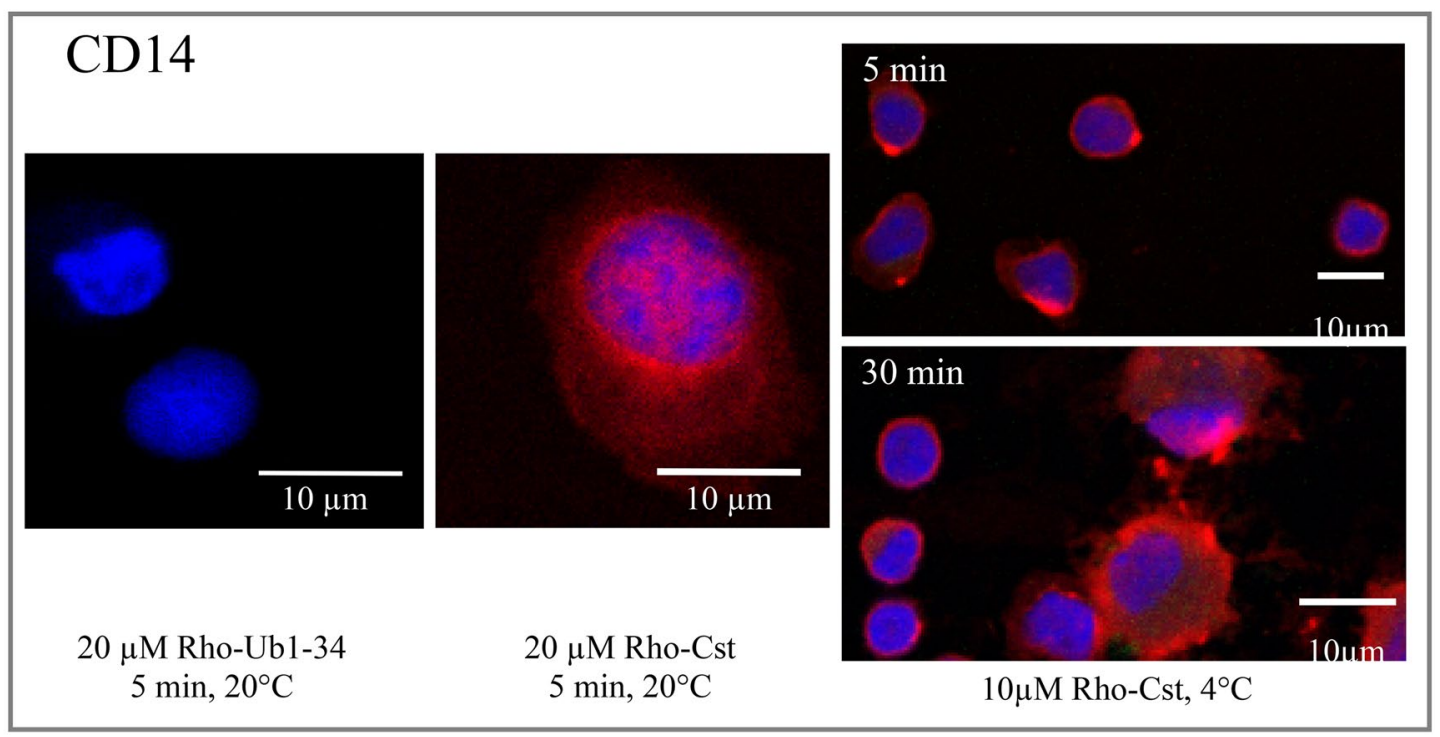

Figure 2. Confocal laser microscope observation of living DC1a (a) and CD14 (b) cells incubated with rhodamine labeled peptides: $20 \mu \mathrm{M}$ Rho-Ub1-34 and $20 \mu \mathrm{M}$ Rho-Cts during $5 \mathrm{~min}$ at $20^{\circ} \mathrm{C}$ and $10 \mu \mathrm{M}$ Rho-Cts during $5 \mathrm{~min}$ and $30 \mathrm{~min}$ at $4{ }^{\circ} \mathrm{C}$.

\section{Results}

Interaction of Cts with immune dermal cells. The sequence of Cts is homologous to that of Penetratin, a CPP (Cell Penetrating Peptide), which penetrates into neutrophils ${ }^{14}$. Herein, we examined the interaction of Cts with different immune cells (Figs. 2 and 3) playing a role in dermal infection development (i.e.: dendritic cells DC1a, dermal macrophages CD14 and macrophages ${ }^{31,32}$ ).

Confocal laser microscope analysis of rhodaminated-Cts (Rho-Cts) incubated with cells was compared with that of Rho-Ub1-34, a peptide unable to penetrate into cells ${ }^{33}$. We detected the penetration and the subsequent localization of $20 \mu \mathrm{M}$ Rho-Cts into the three types of immune cells. After 5 min of incubation with DC1a, $20 \mu \mathrm{M}$ Rho-Cts was detected in the cytoplasm and nucleus (Fig. 2a), whereas its immune-localization was rather accumulating at the nuclear membrane and in some nuclear structures in CD14 cells (Fig. 2b). Finally, in macrophages, we observe a cytoplasmic localization of Rho-Cts with an accumulation in perinuclear vesicles (Fig. 3). In order to investigate the mechanism by which Rho-Cts is penetrating, experiments (performed at $4{ }^{\circ} \mathrm{C}$ for 5 and $30 \mathrm{~min}$ ) confirmed that $20 \mu \mathrm{M}$ Rho-Cts is able to penetrate into DCla and CD14 indicating that endocytosis is not the mechanism of penetration (Fig. 2). These data confirmed that Cts is a CPP and suggest the same property for its active domain Ctl.

In addition, we have examined the release of 4 cytokines, involved in the mechanisms of inflammation, after treatment of cells (harvested from 2 patients) with $15 \mu \mathrm{M}$ Cts (Fig. 4a). IL-6, IL-8, TNF-a display proinflammatory properties and IL-10 anti-inflammatory properties ${ }^{34}$. For CD14, the comparison of the amount of 


\section{Macrophages}

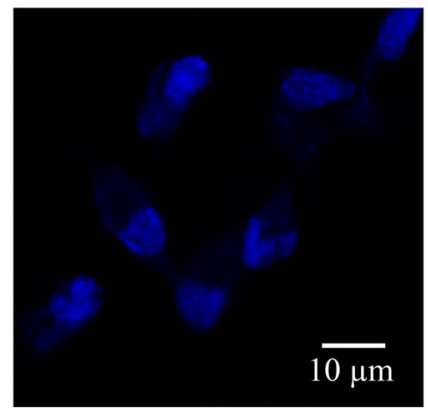

$20 \mu \mathrm{M}$ Rho-Ubi1-34 $20^{\circ} \mathrm{C} 5 \mathrm{~min}$

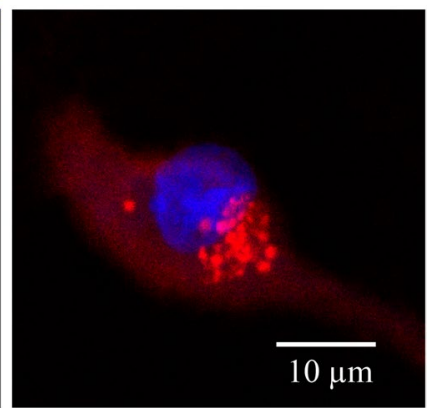

20M Rho-Cts $20^{\circ} \mathrm{C} 5 \mathrm{~min}$

Figure 3. Confocal laser microscope observation of living macrophages incubated with rhodamine labeled peptides: $20 \mu \mathrm{M}$ Rho-Ub1-34 and $20 \mu \mathrm{M}$ Rho-Cts during $5 \mathrm{~min}$ at $20^{\circ} \mathrm{C}$.

IL- 8 released after activation by Cts and controls (treated without peptide), shows a significant decrease of $26 \%$. Furthermore, the production of IL-6, IL-10 and TNF- $\alpha$ is not modified after treatment with Cts.

In order to optimize the antimicrobial activities of Ctl, the active domain of Cts, several dimers separated by PEG linkers and D-isomer forms were synthesized and tested (Fig. 1).

Assessment of the antimicrobial activities of dimeric forms of $\mathrm{Ctl}$ against S. aureus and C. albicans. Peptides covalent dimers with spacers of $\mathrm{n}$ PEG caused rapid and potent killing of pathogenic bacteria ${ }^{35}$. Four different peptides (P3-P6) corresponding to the dimeric form of Ctl with spacers of $\mathrm{n}$ PEG $(\mathrm{n}=3,12,16,46)$ were tested against methicillin sensitive S. aureus (MSSA, strain 49775), methicillin resistant S. aureus (MRSA, strain S1) and C. albicans, (ATCC ${ }^{\odot}$ 10231TM). In recent years, Candida isolates with acquired resistance to azoles and echinocandins have been reported more frequently ${ }^{36}$. The antimicrobial activities were compared with Ctl and Ctl-C (P1, P2) (Table 1). A cysteine residue and a maleimide group were added at the C-terminal end of each monomer used with 3,12, 16 and 46 PEGs (P3-P6). The syntheses were based on the reaction of a linker ended on both sides by 2 maleimide groups and the thiol group of the Ctl-C through the thiolene click reaction. The dimer P3 with 3 PEGs was the only one active against MSSA and MRSA with a MIC of $30 \mu \mathrm{M}$ and $50 \mu \mathrm{M}$ respectively, and also against $C$. albicans with a MIC of $20 \mu \mathrm{M}$, (Table 1). To explain the specific activity of $\mathrm{P} 3$ we propose that the longer PEGs prevent the penetration of the peptide with their antiadhesive properties.

We have examined the ability of $30 \mu \mathrm{M}$ of each peptide (Ctl-C, D-Ctl-C and P3) to release cytokines from PBMCs by using the Bio-Plex Multiplex Immunoassay system (Bio-Rad) which assesses the release of 17 cytokines. We have pointed out the evalutions obtained for IL-6, IL-8, IL-10 and TNF- $\alpha$ (Fig. 4b). We confirmed the data previously obtained for L- and D-Ctl indicating that these 2 peptides and $\mathrm{P} 3$ are unable to induce te release of the tested cytokines. The high variation in TNF- $\alpha$ release does not allow to conclude and it is not presented.

Antimicrobial activities of L- and D- isoforms of Ctl against 79 Gram negative resistant bacteria and C. albicans. D- peptides are resistant to enzyme degradation and are therefore potent antimicrobial agents against pathogenic bacteria ${ }^{25,26,37}$. The antimicrobial activities of the L- and D-isoforms of Ctl (Table 2) were compared with the corresponding scrambled sequences against 75 Gram negative resistant bacteria and against $C$. albicans isolates with acquired resistance to azoles and echinocandins ${ }^{36}$. In addition to wild type, some bacterial strains were noted ESBL, (Extended Spectrum Beta-Lactamase), the most influential mechanism for cephalosporin resistance ${ }^{38}$. Among these strains some are noted CTXM, (the highest level for cefotaxime resistance) a rapidly growing family of ESBLs with significant clinical impact ${ }^{39}$. We can point out that the L-and D-scrambled sequences are inactive against all the tested strains with MICs $>128 \mu \mathrm{g} / \mathrm{mL}(>68.8 \mu \mathrm{M})$ and that the $\mathrm{D}$ - isoform is always more active than the L-Ctl (Table 2).

For E. coli, D-Ctl is active at $8 \mu \mathrm{g} / \mathrm{mL}(4.3 \mu \mathrm{M})$ and $16 \mu \mathrm{g} / \mathrm{mL}(8.6 \mu \mathrm{M})$ against EC195 (Amp C strain) and EC4, Ec46, Ec47, Ec74, Ec71, Ec197, Ec198 respectively. For K. pneumoniae, D-Ctl is active at $32 \mu \mathrm{g} / \mathrm{mL}(17.2 \mu \mathrm{M})$ for B24, B73, B75, (wild type), B49, B50, B68 (CTXM) B101 (ESBL). For E. cloacae, a frequent bacteria isolated in human clinical sample, D-Ctl is active at $32 \mu \mathrm{g} / \mathrm{mL}(17.2 \mu \mathrm{M})$ for B142 (wild type), B43, B57, B167 (ESBL), B38, B44, B96 (Amp C), B113 and B118 (ESBL and OXA 48). Similar data were obtained for: (1) E. aerogenes and C. freundii, with a MIC for D-Ctl of $32 \mu \mathrm{M}(17.2 \mu \mathrm{M})$ against the strains B145, B146, B147 (wild type), B168, B170 (ESBL), B148, B149, B150 (Amp C); (2) for E. aerogenes and B162, B163, B164 (wild type), B165 (Amp C); (3) for $\mathrm{C}$. freundii. All these strains are frequently involved in the the urinary tract infections.

In addition, D-Ctl is active against SA 112 (MSSA) with a MIC of $32 \mu \mathrm{g} / \mathrm{mL}(17.2 \mu \mathrm{M})$, whereas it is active with a MIC of $64 \mu \mathrm{g} / \mathrm{mL}(34.4 \mu \mathrm{M})$ for the others strains. D-Ctl is less active against $P$. aeruginosa with a MIC varying from $64 \mu \mathrm{g} / \mathrm{mL}(34.4 \mu \mathrm{M})$ to $128 \mu \mathrm{g} / \mathrm{mL}(68.8 \mu \mathrm{M})$ and it is inactive against the highly resistant strains $\mathrm{L} 1, \mathrm{~L} 2$ and $\mathrm{L} 3$ of C. albicans. 

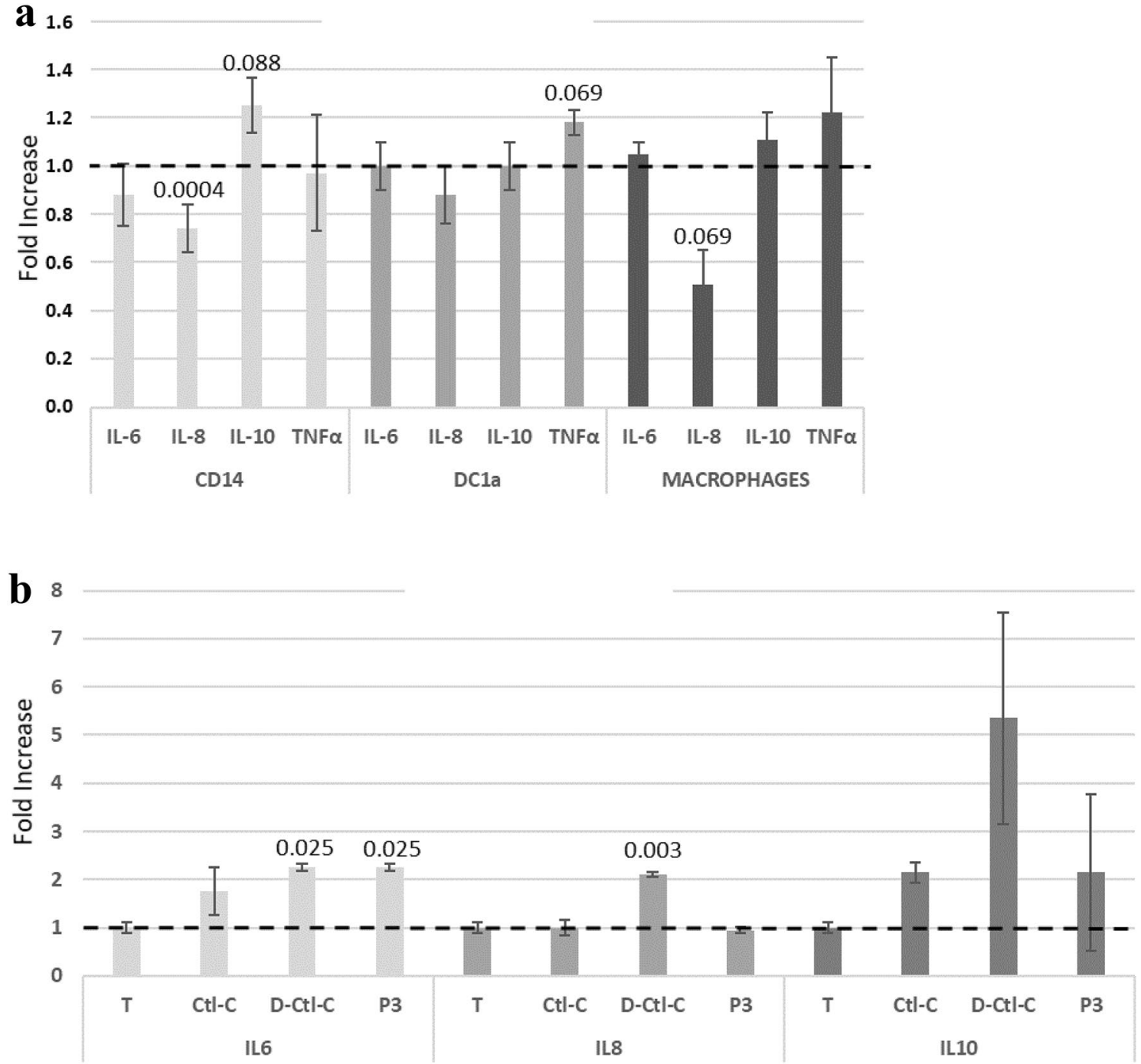

Figure 4. Cytokines assay release: (a) Cells (CD14, DC1a and macrophages) from two healthy volunteers were treated with $15 \mu \mathrm{M}$ Cts from $24 \mathrm{~h}$. The cytokines levels were evaluated in the cell supernatant using the ELISA assay. Fold increase represents the ratio of cytokine release induced by Cts/cytokine release control (without peptide). Data are shown as mean $+/$-standard deviation of two independent experiments; $p$ are indicated. (b) PBMCs from two healthy volunteers were treated with the dimeric form P3 (3 PEGs), Ctl-C and D-Ctl-C. The cytokines levels were evaluated in the cell supernatant using the Bio-Plex technic. Fold increase represents the ratio of cytokine release induced by Cts/cytokine release control (without peptide). Data are shown as mean $+/-$ standard deviation of two independent experiments; $\mathrm{p}$ are indicated.

\begin{tabular}{|l|l|l|l|l|}
\hline & & \multicolumn{3}{l|}{ MIC $_{\mathbf{1 0 0}}(\boldsymbol{\mu} \mathbf{M})$} \\
\cline { 3 - 6 } Peptide & Sequence & MSSA & MRSA & C. albicans \\
\hline P1 & RSMRLSFRARGYGFR & 50 & 100 & 20 \\
\hline P2 & RSMRLSFRARGYGFRC & 60 & 100 & 20 \\
\hline P3 & RSMRLSFRARGYGFRC-(3PEG)-CRFGYGRARFSLRMSR & 30 & 50 & 20 \\
\hline P4 & RSMRLSFRARGYGFRMal-(12PEG)-MalRFGYGRARFSLRMSR & $>100$ & ND & ND \\
\hline P5 & RSMRLSFRARGYGFRMal-(16PEG)-MalRFGYGRARFSLRMSR & $>100$ & $>100$ & 50 \\
\hline P6 & RSMRLSFRARGYGFRMal-(46PEG)-MalRFGYGRARFSLRMSR & $>100$ & ND & ND \\
\hline
\end{tabular}

Table 1. Antimicrobial activity against S. aureus and C. albicans of dimeric forms of Ctl. MSSA (strain 49775) and MRSA (strain S1); C. albicans, (ATCC 10231TM). ND, not determined. 


\begin{tabular}{|c|c|c|c|c|c|c|c|}
\hline Bacterial strain & Type & & Reference & D-Ctl & Control D & L-Ctl & Control L \\
\hline \multirow{12}{*}{ Escherichia coli } & Wild type & & ATCC $6(25,922)$ & 32 & $>128$ & 128 & $>128$ \\
\hline & & & Ec 4 & 16 & 128 & & \\
\hline & & & Ec 204 & 32 & 128 & & \\
\hline & BLSE & CTXM & Ec 46 (C11) & 16 & 128 & $>128$ & $>128$ \\
\hline & & CTXM & Ec 47 (C12) & 16 & $>128$ & & \\
\hline & & CTXM & Ec 70 & 64 & $>128$ & & \\
\hline & & & Ec 73 & 128 & $>128$ & $>128$ & $>128$ \\
\hline & & & Ec 74 & 16 & 128 & & \\
\hline & & & Ec 195 & 8 & 64 & & \\
\hline & OXA 48 & BLSE & Ec 71 & 16 & 128 & & \\
\hline & & & Ec 197 & 16 & 64 & & \\
\hline & & & Ec 198 & 16 & 128 & & \\
\hline \multirow{9}{*}{ Klebsiella pneumoniae } & Wild type & & B-24 & 32 & $>128$ & $>128$ & $>128$ \\
\hline & & & B-73 (C3) & 32 & 128 & & \\
\hline & & & B-75 (C4) & 32 & 128 & & \\
\hline & BLSE & CTXM & B-49 (C2) & 32 & 128 & 128 & $>128$ \\
\hline & & & B-50 & 32 & $>128$ & & \\
\hline & & СТХM & B-68 (C1) & 32 & $>128$ & & \\
\hline & KPC & & B-97 & $>128$ & $>128$ & & \\
\hline & & BLSE & B-101 & 32 & $>128$ & & \\
\hline & & & B-102 & 128 & $>128$ & & \\
\hline \multirow{12}{*}{ Enterobacter cloacae } & Wild type & & B-141 & 128 & $>128$ & $>128$ & $>128$ \\
\hline & & & B-142 & 32 & 128 & & \\
\hline & & & B-144 & 64 & $>128$ & & \\
\hline & BLSE & & B-43 & 32 & $>128$ & $>128$ & $>128$ \\
\hline & & & B-57 & 32 & 128 & & \\
\hline & & & B-167 & 32 & $>128$ & & \\
\hline & Amp C & & B-38 & 32 & $>128$ & & \\
\hline & & & B-44 & 32 & $>128$ & & \\
\hline & & & B-96 & 32 & 128 & & \\
\hline & 0XA 48 & BLSE & B-112 & 64 & 128 & & \\
\hline & & BLSE & B-113 & 32 & 128 & & \\
\hline & & BLSE & B-118 & 32 & 128 & & \\
\hline \multirow{9}{*}{ Enterobacter aerogenes } & Wild type & & B-145 & 32 & 128 & 128 & $>128$ \\
\hline & & & B-146 & 32 & 128 & & \\
\hline & & & B-147 & 32 & 128 & & \\
\hline & BLSE & & B-168 & 32 & $>128$ & $>128$ & $>128$ \\
\hline & & & B-169 & 64 & 128 & & \\
\hline & & & B-170 & 32 & 128 & & \\
\hline & AMP C & & B-148 & 32 & 128 & & \\
\hline & & & B-149 & 32 & 128 & & \\
\hline & & & B-150 & 32 & 128 & & \\
\hline \multirow{6}{*}{ Serratia marcescens } & Wild type & & B-151 & $>128$ & $>128$ & $>128$ & $>128$ \\
\hline & & & B-152 & $>128$ & $>128$ & & \\
\hline & & & B-153 & 128 & $>128$ & & \\
\hline & Amp C & & B-154 & $>128$ & $>128$ & $>128$ & $>128$ \\
\hline & & & B-155 & 128 & $>128$ & & \\
\hline & & & B-156 & 128 & $>128$ & & \\
\hline \multirow{6}{*}{ Morganella morganii } & Wild type & & B-157 & $>128$ & $>128$ & $>128$ & $>128$ \\
\hline & & & B-158 & $>128$ & $>128$ & & \\
\hline & & & B-159 & $>128$ & $>128$ & & \\
\hline & Amp C & & B-59 & $>128$ & $>128$ & $>128$ & $>128$ \\
\hline & & & B-160 & $>128$ & $>128$ & & \\
\hline & & & B-161 & $>128$ & $>128$ & & \\
\hline
\end{tabular}




\begin{tabular}{|c|c|c|c|c|c|c|}
\hline Bacterial strain & Type & Reference & D-Ctl & Control D & L-Ctl & Control L \\
\hline \multirow{6}{*}{ Citrobacter freundii } & Xild type & B-162 & 32 & 128 & 128 & $>128$ \\
\hline & & B-163 & 32 & 128 & & \\
\hline & & B-164 & 32 & 128 & & \\
\hline & Amp C & B-65 & 64 & 128 & $>128$ & $>128$ \\
\hline & & B-165 & 32 & 128 & & \\
\hline & & B-166 & 64 & 128 & & \\
\hline \multirow{3}{*}{ MSSA } & Wild type & ATCC1 $(29,213)$ & 64 & $>64$ & $>128$ & $>128$ \\
\hline & & SA 100 & 64 & $>128$ & & \\
\hline & & SA 112 & 32 & $>128$ & & \\
\hline \multirow{3}{*}{ MRSA } & Wild type & ATCC 21 & 64 & $>128$ & $>128$ & $>128$ \\
\hline & & SA 111 & 64 & $>128$ & $>128$ & $>128$ \\
\hline & & SA 166 & 64 & $>128$ & & \\
\hline \multirow{9}{*}{ Pseudomonas aeruginosa } & Wild type & P-122 & $>128$ & $>128$ & $>128$ & $>128$ \\
\hline & & P-129 & 128 & $>128$ & & \\
\hline & & P-131 & 128 & $>128$ & & \\
\hline & Amp C & P-124 & 128 & $>128$ & $>128$ & $>128$ \\
\hline & & P-125 & 128 & $>128$ & & \\
\hline & & P-85 & 128 & $>128$ & & \\
\hline & VIM & P-144 & 128 & $>128$ & & \\
\hline & & P-149 & 64 & $>128$ & & \\
\hline & & P-150 & 128 & $>128$ & & \\
\hline \multirow{3}{*}{ Candida albicans } & Wild type & L-1 & 256 & 512 & 512 & 512 \\
\hline & & L-2 & 256 & 512 & & \\
\hline & & L-3 & 256 & 512 & & \\
\hline
\end{tabular}

Table 2. Antimicrobial activities of L- and D- Ctl and the corresponding scrambled peptides (controls) against resistant pathogens (MIC, $\mu \mathrm{g} / \mathrm{mL})$.

Because S. aureus is an opportunistic pathogen and the leading cause of a wide range of severe clinical infections ${ }^{27}$, we have designed a new Ctl-derived peptide that will be used to fight this pathogen for on-demand self-killing.

Monitoring of the on-demand release of $\mathrm{Ctl}$ from a tri-blocks peptide to kill S. aureus. The designed peptide $\mathrm{DOPA}_{5} \mathrm{~T}-\mathrm{Ctl}$ is a cationic peptide with a net charge +7 (Supplementary Fig. 1). The three peptides Ctl, TCtl and DOPA 5 T-Ctl were characterized by RP-HPLC and Maldi-Tof mass spectrometry (Supplementary Fig. 2). DOPA 5 T-Ctl $(5$ to $100 \mu \mathrm{M})$ was tested against different strains of $S$. aureus including MSSA (strains 25923, 49775) and MRSA (strain S1 and V8) described in Methods (Fig. 5a). The IC50 values of $20 \mu \mathrm{M}$, $45 \mu \mathrm{M}$, and $65 \mu \mathrm{M}$ were respectively determined for the activity of DOPA ${ }_{5}$ T-Ctl against MSSA (S. aureus 2523, S. aureus 49775) and MRSA (strain S1 and V8) (Fig. 4a). In similar experimental conditions, the antimicrobial properties of DOPA 5 -(D)Ctl against $S$. aureus was investigated and the IC50 value of $35 \mu \mathrm{M}$ was evaluated against the strain 49775 (Data not shown). Differences were all statistically significant $(p<0.05)$.

This antibacterial activity may result of the combination of a direct antimicrobial effect of DOPA 5 T-Ctl and the degradation of DOPA5T-Ctl by proteolytic enzymes from S. aureus and the consequent Ctl release. Indeed, the bacterial lysis induced by DOPA 5 T-Ctl provokes the release of proteolytic enzymes that may act to degrade $\mathrm{DOPA}_{5} \mathrm{~T}$-Ctl, but maintaining $\mathrm{Ctl}$ integrity as previously reported ${ }^{22}$. To investigate this hypothesis, we have tested the possibility of $\mathrm{Ctl}$ releasing from $\mathrm{DOPA}_{5} \mathrm{~T}$-Ctl after proteolysis by the Glu-C endoprotease (E.C. 3.4.21.19) produced by $S$. aureus ${ }^{28}$.

$\mathrm{DOPA}_{5} \mathrm{~T}-\mathrm{Ctl}(1 \mathrm{mg})$ and $\mathrm{T}-\mathrm{Ctl}(1 \mathrm{mg})$ were digested by Glu-C protease in a Tris- $\mathrm{HCl}$ solution according to the experimental procedure reported in Methods. The resulting peptides were isolated with RP-HPLC (Fig. 6a). Mass spectrometry of the major peaks 2 and 8, identified DOPA 5 T $(1425.78 \mathrm{Da})$ and Ctl $(1861.36 \mathrm{Da})$ with the corresponding oxidized forms (1440.77 Da and 1877.25 Da) (Fig. $6 \mathrm{~b}$ and Table 3). This data demonstrates that the major fragments correspond to the cleavage of $\mathrm{DOPA}_{5} \mathrm{~T}-\mathrm{Ctl}$ after the glutamic residue $(\mathrm{E})$ to induce the release of Ctl. Several products of degradation were also isolated: oxidized forms of DOPA $(861.11 \mathrm{Da}, 877.19 \mathrm{Da}$; Fraction 2) and DOPA - TLRG (1272.66 Da; Fraction 2), (Fig. 6b and Table 3). Optical density measurement at 214 $\mathrm{nm}$ indicated the full proteolysis of $\mathrm{DOPA}_{5} \mathrm{~T}-\mathrm{Ctl}$ and $76 \%$ of $\mathrm{Ctl}$ and its oxidized form were released (Fig. 6a). The mass spectra of the minor fractions isolated after HPLC indicated that they correspond to the minor fragments previously indicated in Fractions 2 and 8, but also new fragments (Supplementary Fig. 3 and Table 3). Furthermore, we have shown that the $\mathrm{DOPA}_{5}$ sequence facilitates the release of the full peptide Ctl after action of the Glu-C endoprotease by comparison with T-Ctl which produces predominantly the fragments TLRGGE, 
$\mathbf{a}$
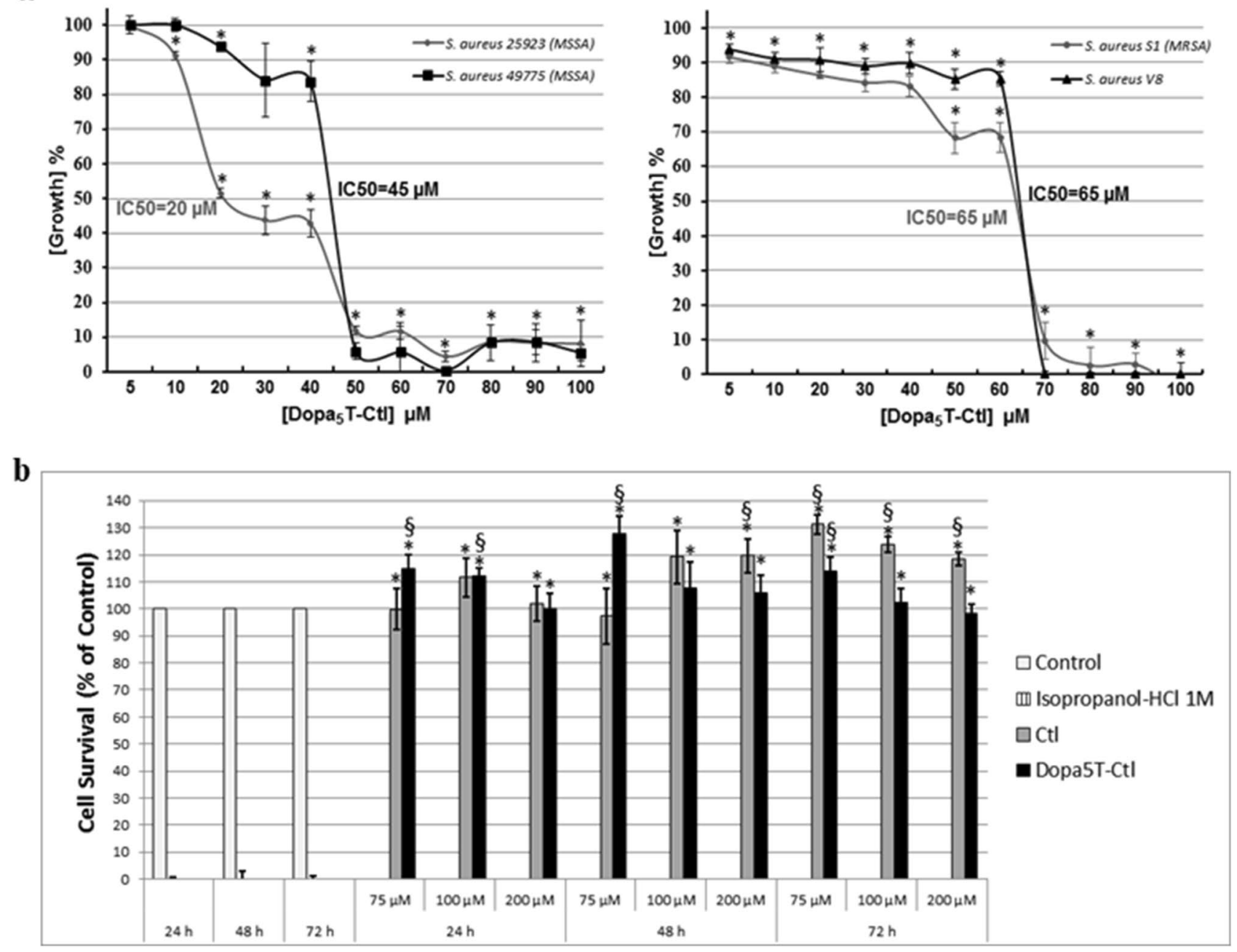

Figure 5. (a) Antimicrobial activity of Dopa ${ }_{5} \mathrm{~T}-\mathrm{Ctl}$ against different strains of $S$. aureus; $\mathrm{t}$-test ${ }^{*} \mathrm{p}<0.05$ for comparison with the positive control, a mixture of Tetracycline $(10 \mathrm{mg} / \mathrm{L})$ and Cefotaxime $(0.1 \mathrm{mg} / \mathrm{L})$. Data are shown as mean $+/$-standard deviation of three independent experiments; (b) Toxicity assay against H9c2 cells. t-test $\$ p<0.05$ for comparison with the positive control ( $100 \%$ of viability, vehicle) and ${ }^{*} \mathrm{p}<0.05$ for comparison with negative control (isopropanol-HCl $1 \mathrm{M}$ ). Data are shown as mean $+/$-standard deviation of three independent experiments.

RSMRLSFR and ARGYGFR (data not shown), with a non-specific cleavage site corresponding to the splitting of the peptidic bond R-A (Supplementary Fig. 1).

H9c2 cells viability. Ctl is not toxic for human gingival fibroblast (HGF-1) ${ }^{26}$ and human intestinal epithelial cell (caco-2) $)^{25}$. Herein, in relation with the properties of $\mathrm{Ctl}$ with the cardiac physiology, biocompatibility of DOPA 5 T-Ctl and Ctl was tested on Rat Cardiac Myoblast Cells (H9C2) with a MTT (3-(4,5-dimethylthiazol2-yl)-2,5-diphenyl tetrazolium bromide) assay. Cell viability is defined as percentage of cells survival relative to that of positive controls (vehicle). For all the tested times of incubation $(24,48$ and $72 \mathrm{~h}$ ) and peptide concentrations $(75,100$ and $200 \mu \mathrm{M})$ the cell viability was close or higher to $100 \%(p<0.05)$ (Fig. 5b). DOPA 5 T-Ctl is not toxic for H9c2 cells. Similar data were obtained for Ctl (Fig. 5b) in line with the fact that the effect of L- and D-Ctl on $\mathrm{H} 9 \mathrm{c} 2$ cells proliferation was recently reported indicating that L-Ctl (1-100 nM) induces a significant increase in cell viability in other settings ${ }^{13}$.

\section{Discussion}

We report that Cts penetrates into DC1a, CD14 and macrophages (Figs. 2, 3) and its detection in the nucleus suggests a possible role in the transcription during neuro-immuno-cutaneous regulation. This data may be related with the fact that Cts penetrates also into $\mathrm{PMNs}^{14}$, activates human mast cells ${ }^{15}$ and induces monocytes chemotaxis $^{16}$. It has also reported that Cts is upregulated upon injury ${ }^{40}$, thus demonstrating a direct link between the neuroendocrine and cutaneous immune systems.

The analysis of the release of 4 cytokines indicates the significant decrease of the pro-inflammatory cytokine IL-8 release from CD14 and suggests that Cts might inhibit the pro-inflammatory process. These data are in 
$\mathrm{A} 214 \mathrm{~nm}$

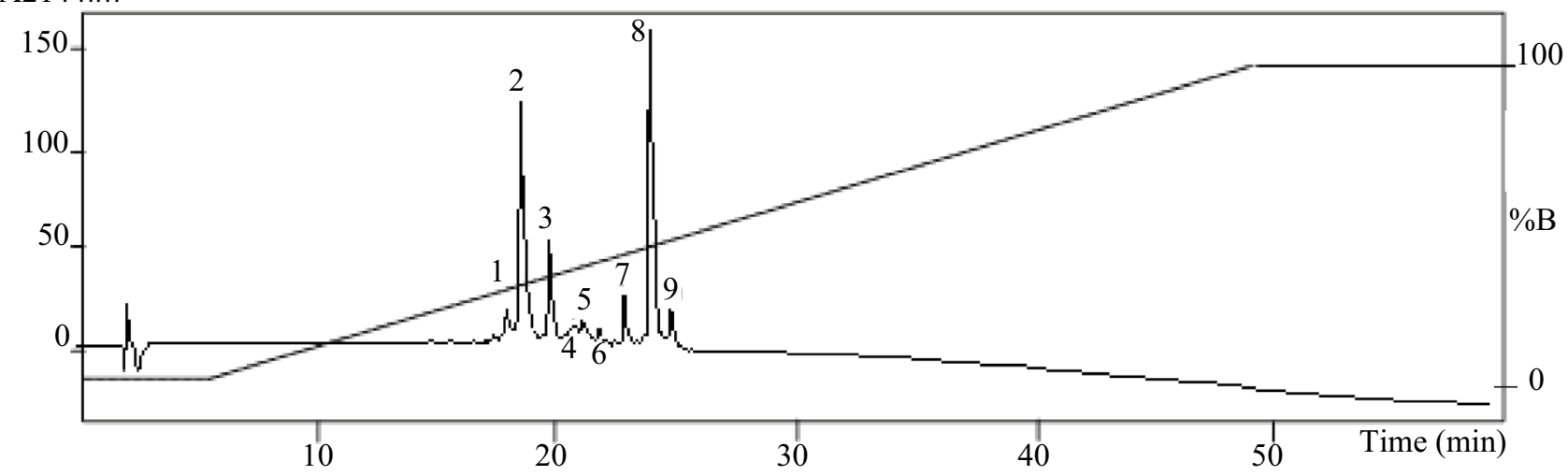

b
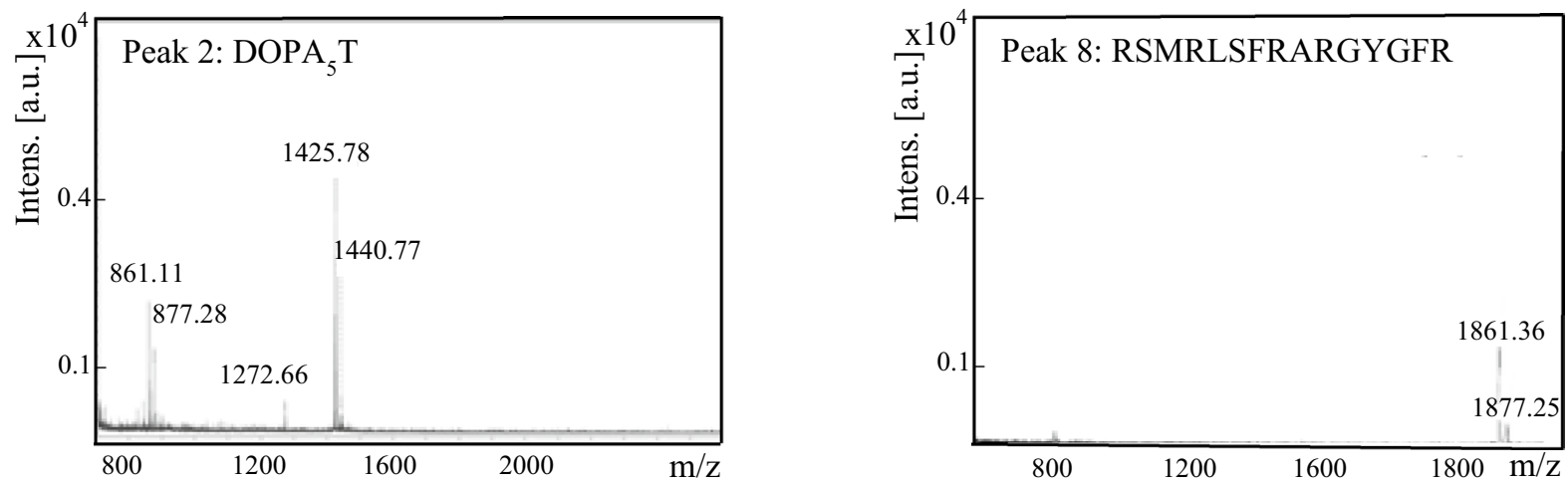

Figure 6. RP-HPLC and identification of the fragments obtained after incubation of DOPA 5 T-Ctl with the endoprotease Glu-C. (a) Chromatogram of the reverse - phase HPLC; gradient of elution is reported on the chromatogram (\%B). (b) Maldi-Tof mass spectrometry of peaks 2 and 8 of the chromatogram. The Maldi-Tof mass spectrometry of minor peaks are reported in Supplementary Fig. 2.

agreement with the property of Cts to modulate local intestinal inflammation through the shifting of macrophage polarization from the pro- to the anti-inflammatory phenotype ${ }^{17,18}$. The limitations of our study may be the low number of patients (2) and the role of Cts with transcription factors. However, according to previous data, Cts interacts with calmodulin to inhibit calcineurin ${ }^{14}$ and the action of Cts is mediated by the $\mathrm{Ca}^{2+}$-Calcineurin-NFAT signaling pathway ${ }^{41}$. Thus, the concept is emerging that Cts plays a role in tissue homeostasis by regulating immune cell infiltration and macrophage differentiation. In a previous paper it was reported that Cst may be incorporated into phospholipid membranes ${ }^{42}$ and that $\mathrm{Ctl}$ interacts with negative lipids inducing rigid membrane domains ${ }^{43}$.

In order to enhance the antimicrobial activity of Ctl against bacterial strains such as $S$. aureus, a series of modifications of the sequences were made on Cts-derived peptides, introducing cysteine, developing dimers separated by PEG linkers and on the D-isomer. Dimerization represents a potent strategy to develop novel antimicrobial agents efficient against resistant bacteria ${ }^{44}$. We have synthesized different peptides and compared their potency with that of the monomeric form Ctl: Ctl-C, Ctl-C-PEG3-C-Ctl and Ctl-Mal-PEG3-Mal-Ctl ( $\mathrm{n}=12,16$, 46).The structure-activity relationship of different dimeric forms of Ctl (the active domain of Cts) supports that the dimeric form including 3 PEGs (P3) improves the antibacterial activity against MSSA (50 $\mu \mathrm{M} ; 93.0 \mu \mathrm{g} / \mathrm{mL}$ to $30 \mu \mathrm{M} ; 55.7 \mu \mathrm{g} / \mathrm{mL})$ and MRSA $(100 \mu \mathrm{M} ; 186 \mu \mathrm{g} / \mathrm{mL}$ to $50 \mu \mathrm{M} ; 93 \mu \mathrm{g} / \mathrm{mL})$ (Table 1$)$. By contrast, the activity against $C$. albicans, (a common pathogen of the skin), of the dimeric form $\mathrm{P} 3$ is similar to that of the monomeric molecule with a MIC of $20 \mu \mathrm{M} ; 37.3 \mu \mathrm{g} / \mathrm{mL}$ (Table 1).

In a new series of experiments we have examined the release of these cytokines after treatment of PBMCs with L- and D-Ctl, Ctl-C, D-Ctl-C and P3 (the short dimer) (Fig. 4b). We confirmed the data previously obtained for $\mathrm{L}$ - and D- Ctl and the dimeric form P3 is also unable to release significantly the tested cytokines. In contrast, the production of IL-8 is increased after activation with D-Ctl-C.

D- analogs of the HDPs were very stable against enzymatic proteolysis $\mathrm{s}^{25,26,35}$ which suggests that their antibacterial activity may increase. This turned out to be always true for D-Ctl against several resistant bacteria (Table 2). The sequence of $\mathrm{Ctl}$ is of most importance for its activity because scrambled peptides did not inhibit microbial growth. D-Ctl is active against several strains of E. coli with a MIC of $8-32 \mu \mathrm{g} / \mathrm{mL}(4.3 \mu \mathrm{M}-17.2 \mu \mathrm{M})$ which may 


\begin{tabular}{|c|c|c|}
\hline Fraction & Molecular mass (Da) & Sequence \\
\hline 1 & 826.42 & Dopa-K-Dopa-K-Dopa + 1(OX) \\
\hline \multirow[t]{5}{*}{2} & 861.11 & Dopa-K-Dopa-K-Dopa + 3(OX) \\
\hline & 877.10 & Dopa-K-Dopa-K-Dopa + 4(OX) \\
\hline & 1272.66 & Dopa-K-Dopa-K-Dopa-TLRG + 2(OX) \\
\hline & 1425.78 & Dopa-K-Dopa-K-Dopa-TLRGGE \\
\hline & 1440.77 & Dopa-K-Dopa-K-Dopa-TLRGGE + 1(OX) \\
\hline \multirow[t]{10}{*}{3} & 861.31 & Dopa-K-Dopa-K-Dopa + 3(OX) \\
\hline & 877.28 & Dopa-K-Dopa-K-Dopa + 4(OX) \\
\hline & 893.26 & Dopa-K-Dopa-K-Dopa + 5(OX) \\
\hline & 909.21 & Dopa-K-Dopa-K-Dopa +-(OX) \\
\hline & 1069.75 & RSMRLSFR + 1(OX) \\
\hline & 1193.98 & TLRGGERSMR + 2(OX) \\
\hline & 1224.01 & TLRGGERSMR + 4(OX) \\
\hline & 1295.04 & RSMRLSFRAR + 1(OX) \\
\hline & 1426.03 & Dopa-K-Dopa-K-Dopa-TLRGGE \\
\hline & 1449.99 & Dopa-K-Dopa-K-Dopa-TLRGGE $+1\left(\mathrm{Na}^{+}\right)$ \\
\hline 4 & 1068.60 & RSMRLSFR + 1(OX) \\
\hline \multirow[t]{3}{*}{5} & 783.51 & RSMRLS + 2(OX) \\
\hline & 920.50 & ARGYGFR + 6(OX) \\
\hline & 1129.73 & FRARGYGFR \\
\hline \multirow[t]{2}{*}{6} & 1052.63 & RSMRLSFR \\
\hline & 1068.62 & RSMRLSFR + 1(OX) \\
\hline 7 & 1875.97 & RSMRLSFRARGYGFR + 1(OX) \\
\hline \multirow[t]{2}{*}{8} & 1861.36 & RSMRLSFRARGYGFR \\
\hline & 1877.25 & RSMRLSFRARGYGFR + 1(OX) \\
\hline 9 & 1633.07 & MRLSFRARGYGFR + 1(OX) \\
\hline
\end{tabular}

Table 3. Maldi-tof analysis of the 9 fractions obtained after HPLC of the digest of Dopa ${ }_{5}$ T-Ctl by the endoprotease Glu-C.

be useful in infections such as that of the gut of newborns within hours after birth causing enterocolitis, urinary tract infections, meningitis and septicemia ${ }^{45}$. Indeed, this data is in accordance with previous results of our group showing that $\mathrm{D}$-Ctl is a new HDP with undetectable susceptibility to resistance and potentiation of the efficiency of several antibiotics (cefotaxime, amoxicillin and methicillin) ${ }^{25}$. The $\mathrm{D}$-isomer of Ctl is also active against $E$. aerogenes and C. freundii with a MIC of $32 \mu \mathrm{g} / \mathrm{ml}(17.2 \mu \mathrm{M})$. In this second part of the study it appears that the $\mathrm{D}$-isomer of $\mathrm{Ctl}$ is the most potent antibacterial Ctl-derived peptide.

Recently, the activity of D-Ctl on two strains of $E$. coli has been examined by using biophysical technics. For all concentrations of D-Ctl, membrane permeabilization was shown, but no pore was observed ${ }^{46}$.

S. aureus is an important agent responsible for the majority of human skin and soft tissue infections ${ }^{47}$. We built up a non-toxic triblock peptide $\left(\mathrm{DOPA}_{5} \mathrm{~T}-\mathrm{Ctl}\right)$ for the on-demand self-killing of $S$. aureus. With a positive charge of $+7, \mathrm{DOPA}_{5} \mathrm{~T}-\mathrm{Ctl}$ can facilitate the antimicrobial activities ${ }^{4,5}$. This study reports that $\mathrm{DOPA}_{5} \mathrm{~T}-\mathrm{Ctl}$ has the capacity to kill several strains of $S$. aureus (Fig. 5a) and that the Glu-C protease of $S$. aureus induces the production of the active Ctl (HPLC and Maldi-Tof mass spectrometry, Fig. 6a,b and Table 3). Antimicrobial activity of DOPA 5 T-(D)-Ctl is in the same range than that with (L)-Ctl with IC50 of $35 \mu \mathrm{M}$ and $45 \mu \mathrm{M}$ respectively. This data suggests that the $\mathrm{D}$-isomer might prevent the action of the endoprotease Glu-C to release (D)-Ctl with a MIC of $17 \mu \mathrm{M}$.

The data obtained in this study show one additional link between the immune and neuroendocrine systems in which Cts interacts with dermal cells and may exert immunomodulatory effects on the cutaneous immune system. In addition, D-Ctl is the most potent Cts-derived antimicrobial peptide against superbugs and the design of a novel non-toxic molecule that permits localized on-demand delivery of an antimicrobial drug directly at the infectious site is described.

\section{Methods}

Preparation and characterization of synthetic Cts and the derived-peptides. The synthetic Cts and the Rhodamine labelled peptide were prepared as previously reported ${ }^{9}$. The chemically synthesized peptides corresponding to L- and D- isomer of Ctl (RSMRLSFRARGYGFR, purity >95\%) and the L and D isomer of the scramble sequence (FMRLRYRSSAFGGRR) were purchased from ProteoGenix (Schiltigheim, France). Dimeric forms of Ctl were synthesized at the Institute Charles Sadron UPR22 CNRS (Strasbourg, France) by Dr. Lydie Séon. These dimeric forms include spacers of $n$ polyethylene glycol (PEG; $n=3,12,16$ and 46); (PEG, 2000 Da, Iris Biotech, Marktredwitz, Germany). A cysteine residue and a maleimide group ( $\mathrm{Mal}$ ) is added at the end of each peptide before the binding to 3, 12, 16 and 46 PEGs (P3, P4, P5 and P6). TLRGGE-RSMRLSFRARGYGFR, 
(T-Ctl) and DOPA-K-DOPA-K-DOPA-TLRGGE-RSMRLSFRARGYGFR (DOPA 5 T-Ctl) were provided from Pepmic (Suzhou, China).

The purity of these peptides was tested by reverse phase (RP) HPLC ${ }^{22}$ with a Dionex HPLC system (Ultimate 3000; 13 Sunnyvale, USA) on a Vydac 208 TP C8 column $(2.1 \times 150 \mathrm{~mm})$ equipped with a pre-column Vydac 208TP $14(7.5 \times 2.1 \mathrm{~mm})($ Vydac, AIT France, Houilles, France) (Supplementary Fig. 2). The solvent system consisted of $0.1 \%(\mathrm{vol} / \mathrm{vol})$ trifluoroacetic acid (TFA) in water (solvent A) and $0.1 \%(\mathrm{vol} / \mathrm{vol})$ TFA in $70 \%$ acetonitrile-water (solvent B) with a flow rate of $0.2 \mathrm{~mL} / \mathrm{min}$. Gradient of elution was indicated on chromatograms and each peak detected at $\lambda 214 \mathrm{~nm}$ was manually collected. Mass spectrometry measurements of material purified from each peak were determined using an Autoflex Maldi-Tof (Matrix Assisted Laser Desorption-Time Of Flight) mass spectrometer (Bruker Daltonics GmbH, Bremen, Germany) at the Laboratoire de Spectrométrie de Masse Bio-Organique, UMR7178 (CNRS-UDS, Strasbourg, France). The matrix solution was prepared from a saturated solution of a-cyano-4-hydroxycinnamic acid in water/acetonitrile 50/50 diluted three times in water/ acetonitrile/trifluoroacetic acid 50/49.9/0.1

Preparation of immune cells. Three types of immune cells were prepared from human monocytes provided from the EFS (Etablissement Français du Sang). Dendritic cells (DC1a), CD14 and macrophages were obtained after treatment of monocytes by cytokines according to the methods previously reported ${ }^{31,32}$ and the identification of the immune cells was validated by using flow cytometry analysis (Fluorescence Activated Cell Sorting, FACS).

Treatment of immune cells by rhodaminated peptides. Rho-Cts ( 10 and $20 \mu \mathrm{M} ; 18.6$ and $37.2 \mu \mathrm{g} /$ $\mathrm{mL})$ was incubated in Hepes buffer $(140 \mathrm{mM} \mathrm{NaCl}, 5 \mathrm{mM} \mathrm{KCl}, 10 \mathrm{mM}$ Hepes$)$ with the three cell types $\left(2.5 \times 10^{5}\right.$ for each assay) for $5 \mathrm{~min}$ at $20^{\circ} \mathrm{C}$. Then, the cells were washed three times with phosphate buffer saline (PBS). The cells were fixed with a solution of paraformaldehyde (PFA) $4 \%$ in PBS for 10 min and washed three times with PBS. Then, the nucleus were labelled for 5 min with DRAQ-5 (1, 5-bis \{[2-(di-methylamino)ethyl]amino $\}$ 4, 8-dihydroxyanthracene-9, 10-dione; dilution 1/500) (BioStatus, Leicestershire, UK). A negative control was obtained with an inactive rhodamine labelled peptide $20 \mu \mathrm{M}$ Rho-Ubil-34, corresponding to the sequence Ubiquitin $1-34^{33}$.

Confocal microscopy. For immune cells treatment experiments, images were taken by confocal microscope. The acquisition was realized at the Plateforme Imagerie In vitro of Neuropôle (Strasbourg, France) by using a LSM 510 invert microscope Zeiss (Oberkofen, Germany) equipped with an immersion objective $(\times 63$, N.A. 1.43).

Antimicrobial assays against $S$. aureus and $C$. albicans. Antibacterial assays were realized to the method previously reported ${ }^{22,25}$. S. aureus strains were pre-cultured for $20 \mathrm{~h}$ in aerobic conditions at $37^{\circ} \mathrm{C}$ in Mueller-Hinton Broth (MHB) medium (Becton-Dickinson Microbiology Company, Sparks, USA) (pH 7.4). Bacteria were suspended at absorbance of 0.001 at $620 \mathrm{~nm}$ in the MHB medium. Antibacterial activity was tested for $24 \mathrm{~h}$ incubation at $37^{\circ} \mathrm{C}$ with shaking by measuring the inhibition of bacterial growth. Ten $\mu \mathrm{l}$ of final volumes $(10-200 \mu \mathrm{g} / \mathrm{mL})$ of synthetic peptides were incubated in microtitration plates with $90 \mu \mathrm{l}$ of a mid-logarithmic phase culture of bacteria, with a starting absorbance of 0.001 at $620 \mathrm{~nm}$. A mixture of Tetracycline $(10 \mathrm{mg} / \mathrm{L})$ and Cefotaxime $(0.1 \mathrm{mg} / \mathrm{L})$ were used as positive controls. Microbial growth was assessed by the increase of absorbance after $24 \mathrm{~h}$ incubation at $37^{\circ} \mathrm{C}$. The A620 nm value of control cultures growing in the absence of peptide and antibiotics was defined as $100 \%$ growth. A620 nm value with the antibiotics (Tetracycline and Cefotaxime) was taken as $100 \%$ inhibition. Absence of bacterial growth was verified by agar plate spreading. Each assay was performed in triplicates. Data were shown as mean $+/-$ standard deviation of three independent experiments; $\mathrm{p}<0.05$.

Antimicrobial assays against C. albicans (ATCC 10231TM) were realized according to the method previously reported $^{26}$. C. albicans was cultured in Sabouraud medium (Sigma-Aldrich, Saint Louis, USA) supplemented with tetracycline $(10 \mu \mathrm{g} / \mathrm{mL})$ and cefotaxime $(10 \mu \mathrm{g} / \mathrm{mL})$ at $37^{\circ} \mathrm{C}$ for $24 \mathrm{~h}$. C. albicans (OD620nm $\left.=0.001\right)$ were plated in 96-well plates and treated either with different concentrations of the peptides of interest, and/or with different concentrations of voriconazole (VCZ) (Sigma-Aldrich, Saint Louis, USA). As a positive control, cells were treated with $10 \mu \mathrm{g} / \mathrm{mL}$ VCZ. After $24 \mathrm{~h}$ incubation, yeast growth was assessed by optical density OD620nm using a spectrophotometer Multiskan EX Microplate Reader Lab (Thermo Fisher Scientific, Waltham, MA, USA).

The MIC of the antifungal agents is defined as the lowest concentration of drug able to inhibit $100 \%$ of the growth of C. albicans.

Antibacterial assays against resistant Gram-negative bacteria and C. albicans. The L- and Dforms of Ctl and also the corresponding L- and D-forms of the scramble peptides were tested by Atlangram (Nantes, France) against resistant Gram-negative bacteria (Escherichia coli, Klebsiella pneumoniae, Enterobacter cloacae, Enterobacter aerogenes, Serratia marcescens, Morganella morganii, Pseudomonas aeruginosa), MSSA, MRSA and yeast (C. albicans). The MICs were determined according to the CASFM/EUCAST 2018 (Comité de l’Antibiogramme de la Société Française de Microbiologie).

In vitro digestion of DOPA5T-CtI by the Glu-C endoprotease. Endoprotease Glu-C from S. aureus V8 (E.C. 3.4.21.19) was provided from Sigma Aldrich (Saint Louis, USA). Digestion of DOPA 5 T-Ctl (12.5 $\mu \mathrm{g})$ by endoprotease Glu-C (Sigma-Aldrich Chemie Saint Quentin Fallavier, France) (3.5 $\mu \mathrm{g})$ was obtained for $18 \mathrm{~h}$ at 
$37^{\circ} \mathrm{C}$ in $50 \mathrm{mM}$ Tris- $\mathrm{HCl} \mathrm{pH} 8.2$ or $\mathrm{PBS}^{28}$. Enzyme $(1.75 \mu \mathrm{g})$ was added for a digestion of $4 \mathrm{~h}$ and then the same amount was added for $18 \mathrm{~h}$. The enzymatic digestion was stopped by addition of $25 \mu \mathrm{L} \mathrm{of} 0.1 \%$ (vol/vol) TFA in milliQ water ${ }^{49}$. The fragments resulting from enzymatic digestion were isolated with a RP-HPLC with a Dionex HPLC system on a Vydac $208 \mathrm{TP} \mathrm{C}_{8}$ column $(3 \times 250 \mathrm{~mm})$, and identified by Maldi-tof mass spectrometry, as previously reported for the characterization of the synthetic peptides ${ }^{22}$.

Cells culture. H9c2 cells (rat embryonic cardiomyocytes) were obtained from American Type Culture Collection (ATCC, Manassas, VA, USA) (Cat\# CRL-1446_H9c2, RRID:CVCL_0286) and maintained in Dulbecco's Modified Eagle Medium/Nutrient Mixture F-12 (DMEM/F-12, Gibco, Thermo Fisher Scientific, Waltham, MA, USA) containing $10 \%$ fetal bovine serum (FBS, Gibco), supplemented with $1 \%$ penicillin/streptomycin (Thermo Fisher Scientific), and incubated at $37^{\circ} \mathrm{C}$ in humidified atmosphere with $5 \% \mathrm{CO} 2$. When the cells reached a density of $80 \%$ in 100 -mm dishes, they were digested using $0.25 \%$ Trypsin-EDTA (1X) (Gibco) according to a $1: 2$ ratio following manufacturer's instructions (ATCC) $)^{50}$.

H9c2 cells viability. H9c2 cell viability was evaluated by 3-(4,5-dimethylthiazol-)2,5- diphenyl tetrazonium bromide (MTT) assay, as previously described ${ }^{13}$. Cells were seeded at a density of $5 \times 103$ cells/well in 96-well plate and incubated for $24 \mathrm{~h}, 48 \mathrm{~h}, 72 \mathrm{~h}$ in a $5 \% \mathrm{CO}_{2}$ incubator at $37^{\circ} \mathrm{C}$ to the following treatments: Positive Control (100\% of viability, vehicle), negative control (1 M isopropanol-HCl), Ctl (75 $\mu \mathrm{M}, 100 \mu \mathrm{M}, 200 \mu \mathrm{M})$ and Dopa5T-Ctl $(75 \mu \mathrm{M}, 100 \mu \mathrm{M}, 200 \mu \mathrm{M})$. At the end of the treatments, the cell culture medium was replaced with $100 \mu \mathrm{l}$ of $2 \mathrm{mg} / \mathrm{ml}$ MTT solution (Sigma Aldrich, Saint Louis USA) and cells were incubated for $3 \mathrm{~h}$ at $37^{\circ} \mathrm{C}, 5 \%$ CO2. After incubation, the solution was removed and the formazan crystals were solubilized by adding $100 \mu$ lof DMSO for $30 \mathrm{~min}$. The absorbance was measured using a Labsystems multiskan (RS-232C, Helsinki, Finland) at $570 \mathrm{~nm}$. Multiskan EX Microplate Reader Lab (Thermo Fisher Scientific, Waltham, MA, USA) at $570 \mathrm{~nm}$. The means of absorbance values of three wells in each experimental group were expressed as the percentage of cell viability. Cell viability was reported as percentage of cells survival relative to positive controls. Each assay was tested in triplicate and data are shown as mean $+/-$ standard deviation of three independent experiments; $\mathrm{p}<0.05$.

Cytokine release assays. The release of cytokines IL-6, IL-8, IL-10 and TNF- $\alpha$ induced after the treatment of immune cells by Cts was realized by the use of an automated ELISA immunoassay (Immulite One, Siemens la Garenne-Colombe, France) and with the Bio-Plex Multiplex Immunoassay system (Bio-Rad, Marnes-laCoquette) for the treatment of Human Peripheral Blood Mononuclear Cells (PBMCs) by L-Ctl, D-Ctl, Ctl-C, D-Ctl-C and P3. PBMCs from healthy volunteers were obtained from the blood transfusion centre of Strasbourg (Etablissement Français du Sang, Strasbourg) and isolated by density gradient centrifugation using Lymphoprep (Stemcell Technologies). PMBC were then maintained in AIM V medium (Thermo Fisher Scientific, Waltham, MA, USA) at $37^{\circ} \mathrm{C}$ in a $5 \% \mathrm{CO} 2$ humidified incubator and treated for $24 \mathrm{~h}$ with $30 \mu \mathrm{M}$ of each peptide (L-Ctl, $\mathrm{D}-\mathrm{Ctl}, \mathrm{Ctl}-\mathrm{C}, \mathrm{D}-\mathrm{Ctl}-\mathrm{C}$ and P3). Three technical replicates were performed for each condition. Supernatants were then filtered and assessed for cytokine dosage according to the manufacturer's instructions.

\section{Data availability}

Sequence of Catestatin/Cateslytin: Uni protKB, CMGA_Bovin P05059.

Received: 16 February 2021; Accepted: 12 July 2021

Published online: 02 August 2021

\section{References}

1. Genovese, C. et al. Molecular epidemiology of antimicrobial resistant microorganisms in the 21th century: A review of the literature. Acta Biomed. 91, 256-273 (2020).

2. Bell, B. G. et al. A systematic review and meta-analysis of the effects of antibiotic consumption on antibiotic resistance. BMC Infect. Dis. 14, 13 (2014).

3. Nseir, S. et al. Relationship between immunosuppression and intensive care unit-acquired multidrug-resistant bacteria: A casecontrol study. Crit. Care Med. 35, 1318-1323 (2007).

4. Afacan, N. J., Yeung, A. T., Pena, O. M. \& Hancock, R. E. Therapeutic potential of host defense peptides in antibiotic-resistant infections. Curr. Pharm. Des. 18, 807-819 (2012).

5. Phan, T. K., Bevins, C. L. \& Hulett, M. D. Editorial: Advances in the immunology of host defense peptide: Mechanisms and applications of antimicrobial functions and beyond. Front. Immunol. 12, 637641 (2021).

6. Metz-Boutigue, M. H., Goumon, Y., Strub, J. M., Lugardon, K. \& Aunis, D. Antimicrobial chromogranins and proenkephalinA-derived peptides: Antibacterial and antifungal activities of chromogranins and proenkephalin-A-derived peptides. Ann. N. Y. Acad. Sci. 992, 168-178 (2003).

7. Shooshtarizadeh, P. et al. The antimicrobial peptides derived from chromogranin/secretogranin family, new actors of innate immunity. Regul. Pept. 165, 102-110 (2010).

8. Aslam, R. et al. Chromogranin A-derived peptides are involved in innate immunity. Curr. Med. Chem. 19, 4115-4123 (2012).

9. Briolat, J. et al. New antimicrobial activity for the catecholamine release-inhibitory peptide from chromogranin A. Cell. Mol. Life Sci. 62, 377-385 (2005).

10. Hook, V. \& Metz-Boutigue, M. H. Protein trafficking to chromaffin granules and proteolytic processing within regulated secretory vesicles of neuroendocrine chromaffin cells. Ann. N. Y. Acad. Sci. 971, 397-405 (2002).

11. Mahata, S. K. et al. Novel autocrine feedback control of catecholamine release. A discrete chromogranin a fragment is a noncompetitive nicotinic cholinergic antagonist. J. Clin. Invest. 100, 1623-1633 (1997).

12. Mahata, S. K., Kiranmayi, M. \& Mahapatra, N. R. Catestatin: a master regulator of cardiovascular functions. Curr. Med. Chem. 25, 1352-1374 (2018).

13. Rocca, C. et al. Cateslytin abrogates lipopolysaccharide-induced cardiomyocyte injury by reducing inflammation and oxidative stress through toll like receptor 4 interaction. Int. Immunopharmacol. 94, 107487 (2021). 
14. Zhang, D. et al. Two chromogranin A-derived peptides induce calcium entry in human neutrophils by calmodulin-regulated calcium independent phospholipase A2. PLoS ONE 4, e4501 (2009).

15. Aung, G. et al. Catestatin, a neuroendocrine antimicrobial peptide, induces human mast cell migration, degranulation and production of cytokines and chemokines. Immunology 32, 527-539 (2011).

16. Egger, M. et al. Monocyte migration: a novel effect and signaling pathways of catestatin. Eur. J. Pharmacol. 598, 104-111 (2008).

17. Eissa, N. et al. Catestatin regulates epithelial cell dynamics to improve intestinal inflammation. Vaccines 6, 67 (2018).

18. Rabbi, M. F., Labis, B., Metz-Boutigue, M. H., Bernstein, C. N. \& Ghia, J. E. Catestatin decreases macrophage function in two mouse models of experimental colitis. Biochem. Pharmacol. 89, 386-398 (2014).

19. Muntjewerff, E. M., Dunkel, G., Nicolasen, M. J. T., Mahata, S. K. \& van den Bogaart, G. Catestatin as a target for treatment of inflammatory diseases. Front. Immunol. 9, 2199-2208 (2018).

20. Chen, Y. et al. Decreased circulating catestatin levels are associated with coronary artery disease: The emerging anti-inflammatory role. Atherosclerosis 281, 78-88 (2019).

21. Mahata, S. K., Mahata, M., Wakade, A. R. \& O'Connor, D. T. Primary structure and function of the catecholamine release inhibitory peptide Catestatin (Chromogranin A344-364): Identification of amino acid residues crucial for activity. Mol. Endocrinol. 14, $1525-1535$ (2000).

22. Aslam, R. et al. Cateslytin, a chromogranin A derived peptide is active against Staphylococcus aureus and resistant to degradation by its proteases. PLOS ONE 8, e68993 (2013).

23. Cado, G. et al. Self-defensive biomaterial coating against bacteria and yeasts: Polysaccharide multilayer film with embedded antimicrobial peptide. Adv. Funct. Mater. 23, 4801-4809 (2013).

24. Mateescu, M. et al. Antibacterial peptide-based gel for prevention of medical implanted-device infection. PLoS ONE 10, e0145143 (2015).

25. Zaet, A. et al. D-Cateslytin, a new antimicrobial peptide with therapeutic potential. Sci. Rep. 7, 15199-15210 (2017).

26. Dartevelle, P. et al. D-Cateslytin: A new antifungal agent for the treatment of oral Candida albicans associated infections. Sci. Rep. 8, 9235-9244 (2018).

27. Fung, H. B., Chang, J. Y. \& Kuczynski, S. A practical guide to the treatment of complicated skin and soft tissue infections. Drugs 63, 1459-1480 (2003).

28. Houmard, J. \& Drapeau, G. R. Staphylococcal protease: A proteolytic enzyme specific for glutamoyl bonds. Proc. Natl. Acad. Sci. U.S.A. 69, 3506-3509 (1972).

29. Li, Y. et al. Molecular design principles of Lysine-DOPA wet adhesion. Nat. Commun. 11, 3895-3902 (2020).

30. Maier, G. P., Rapp, M. V., Waite, J. H., Israelachvili, J. N. \& Butler, A. Biological adhesives. Adaptive synergy between catechol and lysine promotes wet adhesion by surface salt displacement. Science 349, 628-632 (2015).

31. Kwan, W. H. et al. Dermal-type macrophages expressing CD209/DC-SIGN show inherent resistance to dengue virus growth. PLoS. Negl. Trop. Dis. 2, e311 (2008).

32. Komuro, I., Yokota, Y., Yasuda, S., Iwamoto, A. \& Kagawa, K. S. CSF-induced and HIV-1-mediated distinct regulation of Hck and $\mathrm{C} / \mathrm{EBPb}$ represent a heterogeneous susceptibility of monocyte-derived macrophages to M-tropic HIV-1 infection. J. Exp. Med. 198, 443-453 (2003).

33. Kieffer, A. E. et al. The $\mathrm{N}$ - and C-terminal fragments of ubiquitin are important for the antimicrobial activities. Faseb J. 17, 776-778 (2003).

34. Atri, C., Guerfali, F. Z. \& Laouini, D. Role of human macrophage polarization in inflammation during infectious diseases. Int. J. Mol. Sci. 19, 1801-1815 (2018).

35. Cui, Q. et al. Preparation, characterization and pharmacokinetic study of N-terminal PEGylated D-form antimicrobial peptide OM19r-8. J. Pharm. Sci. 110, 1111-1119 (2021).

36. Colombo, A. L., Júnior, J. N. A. \& Guinea, J. Emerging multidrug-resistant Candida species. Curr. Opin. Infect. Dis. 30, 528-538 (2017).

37. Wade, D. et al. All-D amino acid-containing channel-forming antibiotic peptides. Proc. Natl. Acad. Sci.U S. A. 87, 4761-4765 (1990).

38. Livermore, D. M. $\beta$-lactamases in laboratory and clinical resistance. Clin. Microbiol. Rev. 8, 557-584 (1995).

39. Higa, S. et al. Characterization of CTX-M type ESBL-producing Enterobacteriaceae isolated from asymptomatic healthy individuals who live in a community of the Okinawa prefecture, Japan. J. Infect. Chemother. 25, 314-317 (2019).

40. Radek, K. et al. The neuroendocrine peptide catestatin is a cutaneous antimicrobial and induced in the skin after injury. J. Invest. Dermatol. 128, 1525-1534 (2008).

41. Guo, X., Zhou, C. \& Sun, N. The neuropeptide catestatin promotes vascular smooth muscle cell proliferation through the Ca2+calcineurin-NFAT signaling pathway. Biochem. Biophys. Res. Commun. 407, 807-812 (2011).

42. Khemtémourian, L., Bathany, K., Schmitter, J. M. \& Dufourc, E. J. Fast and quantitative recovery of hydrophobic and amphipathic peptides after incorporation into phospholipid membranes. Anal. Chem. 78, 5348-5353 (2006).

43. Jean-François, F. et al. Aggregation of cateslytin beta-sheets on negatively charged lipids promotes rigid membrane domains. A new mode of action for antimicrobial peptides?. Biochemistry 47, 6394-6402 (2008).

44. Zhong, C. et al. Study on the effects of different dimerization positions on biological activity of partial d-Amino acid substitution analogues of Anoplin. Microb. Pathog. 139, 103871 (2020).

45. Mendoza-Palomar, N. et al. Escherichia coli early-onset sepsis: Trends over two decades. Eur. J. Pediatr. 176, 1227-1234 (2017).

46. Quilès, F., Barth, D., Peric, O., Fantner, G. E. \& Francius, G. Parietal structures of Escherichia coli can impact the D-cateslytin antibacterial activity. ACS Chem. Biol. 15, 2801-2814 (2020).

47. Fridkin, S. K. et al. Active bacterial core surveillance program of the emerging infections program network. Methicillin-resistant Staphylococcus aureus disease in three communities. N. Engl. J. Med. 352, 1436-1444 (2005).

48. Worm, O. \& Mann, M. Improved mass accuracy in matrix-assisted laser desorption/ionization time-of-flight mass spectrometry of peptides. J. Am. Soc. Mass Spectrom. 5, 955-958 (1994).

49. Metz-Boutigue, M. H. et al. Human lactotransferrin: Amino acid sequence and structural comparisons with other transferrins. Eur. J. Biochem. 145, 659-676 (1984).

50. Rocca, C. et al. Notch1 mediates preconditioning protection induced by GPER in normotensive and hypertensive female rat hearts. Front. Physiol. 9, 521-531 (2018).

\section{Acknowledgements}

The authors thank Drs Pierre Schaaf and Philippe Lavalle (INERM_UMR 1121) for their contribution to the design of the Dopa ${ }_{5}$ T-Ctl peptide, Dr Evelyne Schaffer (CNRS UPR3572, Immunopathologie et Chimie Thérapeutique, Laboratory of Excellence Medalis, Institut de Biologie Moléculaire et Cellulaire, Strasbourg, France), the Plateforme Imagerie In Vitro du Neuropôle, (CNRS UPS 3156, Strasbourg, France), the EFS (Etablissement Français du Sang) for the preparation of immune cells, the Institute of Bacteriology of Strasbourg for providing S. aureus strains, Atlangram company (Nantes, France) for antimicrobial assays against several resistant microorganisms and Dr. Nancy Grant for writing assistance. 


\title{
Author contributions
}

M.H.M.B., conception and design of the study, analysis and interpretation of data, drafting the manuscript, final approval of the version to be submitted. F.Sc. acquisition of data, analysis and interpretation of data, drafting the manuscript, final approval of the version to be submitted. A.M., S.C.G., J.M.S., S.C., acquisition of data, analysis and interpretation of data, final approval of the version to be submitted. S.H., acquisition of data, analysis and interpretation of data, drafting of the figures and tables, final approval of the version to be submitted. F.S., revising it critically for intellectual content, final approval of the version to be submitted. Y.H., revising it critically for intellectual content, final approval of the version to be submitted.

\section{Funding}

This study was financially supported by INSERM, the University of Strasbourg and the Proteomic French Infrastructure (ProFI; ANR-10-INSB-08-03). Francesco Scavello was supported by the University 'Italo-Francese' in the context of 'Vinci Project 2014' ( ${ }^{\circ}$ C2-72) attributed to the Department of Biology, Ecology and Earth Science University of Calabria, Arcavacata di Rende, Italy and the INSERM_UMR 1121, Biomaterials and BioEngeneering, Strasbourg, France.

\section{Competing interests}

The authors declare no competing interests.

\section{Additional information}

Supplementary Information The online version contains supplementary material available at https://doi.org/ 10.1038/s41598-021-94749-6.

Correspondence and requests for materials should be addressed to M.-H.M.-B.

Reprints and permissions information is available at www.nature.com/reprints.

Publisher's note Springer Nature remains neutral with regard to jurisdictional claims in published maps and institutional affiliations.

\begin{abstract}
Open Access This article is licensed under a Creative Commons Attribution 4.0 International License, which permits use, sharing, adaptation, distribution and reproduction in any medium or format, as long as you give appropriate credit to the original author(s) and the source, provide a link to the Creative Commons licence, and indicate if changes were made. The images or other third party material in this article are included in the article's Creative Commons licence, unless indicated otherwise in a credit line to the material. If material is not included in the article's Creative Commons licence and your intended use is not permitted by statutory regulation or exceeds the permitted use, you will need to obtain permission directly from the copyright holder. To view a copy of this licence, visit http://creativecommons.org/licenses/by/4.0/.
\end{abstract}

(C) The Author(s) 2021 